\title{
Linking Leadership Studies to Corporate Brand Management: A Review
}

\author{
Zullina H. Shaari ${ }^{1}$, Amzairi Amar ${ }^{1}$, M. Radzi Zainol ${ }^{1}$ \& Azamudin Badri Harun ${ }^{1}$ \\ ${ }^{1}$ Department of Management and Humanities, Universiti Teknologi PETRONAS, Perak, Malaysia \\ Correspondence: Zullina H. Shaari, Department of Management and Humanities, Universiti Teknologi PETRONAS, \\ 31750 Tronoh, Perak, Malaysia. Tel: 60-5-368-7736. E-mail: zullina_shaari@petronas.com.my
}

Received: December 9, 2014

Accepted: December 23, $2014 \quad$ Online Published: December 29, 2014

doi:10.5430/ijba.v6n1p26

URL: http://dx.doi.org/10.5430/ijba.v6n1p26

\begin{abstract}
Two models of corporate brand or reputation management include "leadership and success" as a dimension that influences reactions of multiple stakeholders to organisations. Primary groups of stakeholders such as shareholders/investors, employees, and customers, often associate leadership of organisations with Chief Executive Officers (CEOs) or managing directors. This paper proposes that if CEOs are to be capitalised as part of corporate brand management, their leadership should be projected clearly to stakeholders to influence stakeholder attitudes. Although some studies tend to focus on linking leadership brands and transformational leadership to employees' commitment, little is known what type(s) of leadership is (are) attractive to multiple stakeholders. Both, leadership brands and transformational leadership, can be presented as leadership archetypes, that is, personifications of abstract leadership qualities summing up leaders' traits and behaviours in situational contexts. Using the Competing Values Framework (CVF) for leadership, the researchers reviewed publications of CEO leadership in situational contexts and classified the CEO leadership roles based on the respective scholars' conceptual definitions. The classification revealed that CEOs were perceived as playing multiple leadership roles, which are manifested into leadership archetypes. The archetypes were derived from respondents' perceptions and had different labels subject to the situational contexts. Some of the archetypes reflect CEO functional roles, whilst others were metaphoric. A few leadership archetypes were common across academic literature, whilst others were not. These archetypes offer explicit representations of "leadership" dimension of the CBM models and can assist image generators to gauge which leadership archetypes are excellent or appealing to multiple stakeholders.
\end{abstract}

Keywords: leadership archetypes, CEOs, corporate brand, reputation, metaphors, the CVF

\section{Introduction}

In corporate marketing, corporate brand management (CBM) or reputation can be represented as "the overall estimation in which a company is held by its constituents....., the 'net' affective or emotional reaction - good, bad, weak, or strong - of customers, investors, employees, and general public to the company's name" (Fombrun, 1996 cited in Reil and Fombrun, 2007, p. 44). This definition treats CBM as an evaluative judgement (Clardy, 2010). Several models have been developed to assess CBM, namely, Brand Asset Valuator (BAV), BrandZ, Equitrend, Brand Power, USA's Most Admired, Reputation Quotient $\left(\mathrm{RQ}^{\mathrm{sm}}\right)$ and RepTrak ${ }^{\circledR}$ Scorecard (Reil and Fombrun, 2007). Of these models, $\mathrm{RQ}^{\mathrm{m}}$ and RepTrak ${ }^{\circledR}$ Scorecard are closely similar and include leadership as one of the elements contributing to $\mathrm{CBM}$ or corporate reputation. The $\mathrm{RQ}^{\mathrm{m}}$ has six dimensions (i.e. emotional appeal, product and services, visions and leadership, workplace environment, financial performance and social responsibility). These dimensions were identified through the 1998-to-2000 mixed method research in USA, Australia, and Europe (Reil and Fombrun, 2007). The leadership component consists of capitalizing market opportunities, possessing excellent leadership and having clear vision for the future. The RepTrak ${ }^{\circledR}$ Scorecard has listed seven dimensions (i.e. performance, products/services, innovations, workplace, governance, citizenship and leadership). The scorecard was "created from qualitative and quantitative research conducted in six countries...since 1999" (Reil and Fombrun, 2007, p. 253). The leadership dimension comprises an appealing leader, excellent management, clear vision for the future as well as being well-organised. However, both models have not defined the meaning of excellent leadership and appealing leaders nor did specify whose leadership should be evaluated.

Leadership studies in organisations often refer to organisational leadership, which has two connotations: leadership in organisations and leadership of organisations (Dublin, 1977). Leadership in organisations represents the lower-level leadership in organisational hierarchy (Hunt, 2004). This leadership is often evaluated by the 
organisational members. Leadership of organisations refers the strategic leadership that "connotes management of overall enterprise... and implies substantive decision making responsibilities, beyond the interpersonal and relational aspects usually associated with leadership (in organisations)" (Finkelstein et al., 2009, p. 4). The leadership is characterized as "a person's ability to anticipate, envision, maintain flexibility, think strategically, and work with others to initiate changes that will create a viable future for the organisation" (Ireland and Hitt, 2005, p.63). Such ability is often summarised as leadership archetypes, that is, personifications of abstract leadership qualities summing up leaders' traits and behaviours in situational contexts. This paper aims to summarise leadership archetypes identified by management scholars for researchers (i.e. marketing and management) and practitioners. These archetypes can represent more explicit representations of "leadership" or "leaders" specified by the two CBM models to expand research in corporate brand and reputation. They can provide bases for image generators to plan how CEOs can be capitalised beyond brand endorsers or spokespersons for product or corporate marketing. Besides, the archetypes can also be a starting point in developing brands for organisational leaders that match the vision and missions of organisations.

\section{Material Studied}

The highest ranking corporate officers such as Chief Executive Officers (CEOs) or managing directors compared to leaders at the lower rank such as the managers and supervisors are often associated with strategic leadership (Finkelstein et al., 2009; Boal and Hooijiberg, 2000; Hunt, 2004). CEOs are in charge of the management of organisations and "enact the most visible leadership role" for an organisation (Kitchen and Laurence, 2003, p. 106). Studies investigating the influence of CEO leadership on capital market described CEOs as charismatic leaders (Collins, 2001; Agle et al., 2006; Fanelli, 2003; Agle, et al., 1999; Harris and Ogbonna, 2001; Waldman, et al., 2001, 2004; Tosi et al., 2004; Flynn Staw, 2004). For customer market, studies on CEOs were limited to CEOs being brand endorsers (Rubin et al., 1982), and spokespersons (Reidenbach and Pitts, 1986; Freiden, 1984) of products and firms. Other than being credible brand endorsers and spokespersons, not much is known what types of CEO images are presented to customers. For example, among customers, studies found that the reputation of CEOs and directors was one of the cues used in evaluating corporate image of firms (Shandwick, 2012; LeBlanc and Nguyen, 1996), but offered no clear definition of CEO reputation.

For multiple stakeholders, CEOs are the most accessible touch point contributing to evaluation of CBM or corporate reputation (Fombrum and Riel, 1997; Hatch and Schultz, 1997; Knox and Bickerton, 2003; Page and Fearn, 2005). Leader image has a spill-over effect on organisational image and is vital for corporate branding (Power et al., 2008). "A CEO or managing director, if associated with a corporate brand, must be willing to maintain a more public profile to help to communicate news and information" (Keller, 2008, p.4). Often, a public profile leads CEOs to be perceived as "exemplary individuals... where their actions, personalities and/or private lives function symbolically to represent significant dynamics, and sometimes alleviate significant tensions, prevalent in the contemporary business environment" (Guthey et al., 2009, p. 13). This paper argues that CEOs' actions and attributes are often framed into situational contexts.

Table 1. Transformational leadership theory: aspects of leadership

\begin{tabular}{ccc}
\hline $\begin{array}{c}\text { Five Central Leaders' Traits } \\
\text { (Northhouse, 2010) }\end{array}$ & $\begin{array}{c}\text { Three Behavioural } \\
\text { Meta-Categories } \\
(\text { Yukl, 2006; Yukl et al, 2002) }\end{array}$ & $\begin{array}{c}\text { Two Situational Contexts of } \\
\text { Leadership } \\
\text { (Sashkin, 2004) }\end{array}$ \\
\hline Intelligence & Task & Organisational Cultures \\
Self-confidence & Relation & (i.e. Social Systems) \\
Determination & Change & Organisational Structures \\
Integrity & & (i.e. Hierarchy) \\
Sociability & & \\
\hline
\end{tabular}

In leadership studies, leaders' actions (i.e. leaders' behaviours), personality (i.e. leaders' traits and attributes) and situations (i,e. contingency and situational leadership) represent part of major schools of leadership and each suggests multiple approaches (see Antonakis et al, 2004 and Northouse, 2010). These three schools of leadership can be represented as transformational leadership that is originated from Burns' (1978) transformational leadership theory (TLT), a hybrid leadership theory (Sashkin, 2004). The theory combines three basic aspects of leadership, 
namely, leader personal characteristics, leader behaviour, and situational contexts as illustrated in Table 1 (see Sashkin, 2004 for review).

Some early researchers have attempted to identify the most effective leadership for CEOs according to situational contexts (e.g. Leontiades, 1982; Wissema et al., 1980). These studies are consistent with the contingency approaches of leadership such as Fiedler's (1967) contingency model, Hersey and Blanchard's (1982) situational theory, and the Vroom-Jago's (1988) contingency model. These approaches argue that effective leadership styles are subject to specific situations (Daft, 2005). This notion is also known as leader-match concept (Northouse, 2010). However, the match often refers to fitting leadership styles (i.e. leadership behaviours) into situational contexts, and appears to ignore leaders' traits and attributes. Current management scholars assert that CEOs should apply the transformational leadership (Hitt et al., 2007). This assertion suggests that CEOs leadership is a manifestation of CEOs' traits and behaviours in situational contexts. In this paper, such a manifestation is defined as leadership archetypes, that is, personifications of abstract leadership qualities summing up leaders' traits and behaviours in situational contexts. Yet, little is known what strategic leadership archetypes have been identified by scholars.

\section{Flexibility and Discretion}

\begin{tabular}{|c|c|}
\hline $\begin{array}{l}\text { Collaborate-Orientation } \\
\text { Leader type: Facilitator, Mentor } \\
\text { Value drivers: Commitment, Communication, } \\
\text { Development } \\
\text { Theory of Effectiveness: Human development } \\
\text { and participation produce effectiveness }\end{array}$ & $\begin{array}{c}\text { Create-Orientation } \\
\text { Leader type: Innovator, Visionary } \\
\text { Value drivers: Innovative outputs, } \\
\text { Transformation, Agility } \\
\text { Theory of Effectiveness: Innovativeness, } \\
\text { vision, and new resources produce } \\
\text { effectiveness }\end{array}$ \\
\hline $\begin{array}{c}\text { Control-Orientation } \\
\text { Leader type: Coordinator, Monitor } \\
\text { Value drivers: Efficiency, Timeliness, } \\
\text { Consistency and uniformity } \\
\text { Theory of Effectiveness: Control and } \\
\text { efficiency with capable processes produce } \\
\text { effectiveness }\end{array}$ & $\begin{array}{c}\text { Compete-Orientation } \\
\text { Leader type: Competitor, Producer } \\
\text { Value drivers: Market share, Goal } \\
\text { Achievement, Profitability } \\
\text { Theory of Effectiveness: Aggressively } \\
\text { competing and customer focus produce } \\
\text { effectiveness }\end{array}$ \\
\hline
\end{tabular}

\section{Stability and Control}

Figure 1. Competing values framework for leadership

Adapted from (Cameron et al. (2006)

An emergent theory for strategic leadership that suggests leadership archetypes refers to Cameron, et al.'s (2006) competing value framework (CVF) for leadership as illustrated in Figure 1 (Boal and Hooijberg, 2001). The CVF has four quadrants of orientation: collaborate, create, compete and control. It has been used as a broadly applicable model to foster successful leadership, improve organisational effectiveness and promote value creation (Cameron et al, 2006). The CVF contends that effective leadership improves organisational performance, which creates values (i.e. financial and human capital). The collaborate-orientation emphasises flexibility-and-discretion and internal-factors-integration. This leadership orientation requires leaders who are warm and supportive to manage teams (commitment), interpersonal relationships (communication) and the development of others (development). Leaders act as facilitators and mentors whose effectiveness is translated into sensitivity to customers and concern for people. The create-orientation focuses on flexibility-and-discretion and external-factors-and-differentiation. It 
requires leaders who break rules to manage innovation (innovative outputs), the future (transformation) and continuous improvement (agility). Leaders act as innovators and visionaries whose effectiveness refers to generating unique and new products or services.

The compete-orientation focuses on stability-and-control and has external-focus-and-differentiation. This orientation requires leaders to be tough and demanding in order to manage competitiveness and customer service (market share and profitability), and energise employees (goal achievement). Leaders act as competitors and producers whose effectiveness is reflected in improving profitability, market share and financial performance. The control-orientation focuses on stability-and-control and has internal-focus-and-differentiation. This orientation requires leaders who reinforce rules to manage coordination (timeliness), the control system (efficiency), and acculturation (consistency and uniformity). Leaders following this orientation are monitors and coordinator whose effectiveness is manifested through dependable delivery, smooth scheduling and low cost. In short, each quadrant theorises that organisational effectiveness is subject to the leader-context match. Leader types or roles are leadership archetypes (i.e. personifications of abstract leadership qualities such as the commander, the fighter, the visionary, etc.) should match situational contexts (i.e. organisational orientations).

Though the match concept has been suggested by the CVF, most CEO leadership studies have not clearly associated their findings with the same concept. This paper illustrates how findings of previous research actually represent CEO leadership archetypes (i.e. personifications of abstract leadership qualities summing up leaders' traits and behaviours in situational contexts) and can be associated with the CVF for leadership. These leadership archetypes could have more holistic representation of CEOs as part of organisational leadership and success (i.e. a dimension of CBM) compared to random information about CEOs.

This paper argues that public profiles of CEOs often portray CEOs' leadership archetypes to stakeholders. These archetypes such as the commander, the fighter, the visionary, etc. are images held by the stakeholders and "not picture(s)... (or) detailed representation(s), (but)... rather, a few details softened with the fuzziness of perception" (Newsom et al, 1989, p. 364) and should be part of CBM. CEO leadership archetypes may signal to multiple stakeholders that the CEOs are highly skilful and competent leaders and likely to improve their firms' performances (Wade et al., 2008). The paper presents a review of CEO leadership in situational contexts and suggests that leadership archetypes of CEOs can be capitalised to contribute to the CBM.

\section{Method}

A review of the leader-context match concept in academic literature was carried out. The scholarly publications selected included journal articles, leadership books and working paper series. Using the CVF framework, the identified leaders in situational contexts were fit into each quadrants based on the conceptual definitions of the respective authors. In other words, the CVF provides the basis for organising previous research findings on CEO leadership in situational contexts (i.e. the organisational critical and contemporary issues).

The online search for full text and peer reviewed articles up to 2012 through the ProQuest database led to 1355 articles on leadership archetypes (i.e. the personification of abstract leadership qualities, namely, traits and behaviours in situational contexts) and 558 articles on CEO archetypes. These articles were shortlisted to include only CEO leadership in situational contexts. The process suggested that only limited number of articles (i.e. only 6 articles) specifically investigated CEO leadership in situational contexts. Each one was extracted from the Administrative Science Quarterly, Creativity and Innovation Management, Harvard Business Review, Human Relations, Leadership Quarterly, Organisation Studies, and Organisational Dynamics, for analysis (see References). Two books entitled Metaphors We Lead By and In Their Time: The Greatest Business Leaders of the Twentieth Century and one Harvard University faculty research working paper series were also reviewed to summarise leadership archetypes in academic literature. Another online search using a popular search engine focusing on scholarly articles on CEO leadership up to 2014 hit 7720 results. Of these articles, a few scholars have written about leadership archetypes between 2013 and 2014 and associated them with Jung's (1980) twelve archetypes, namely, caregiver, ruler, creator, sage, explorer, innocent, outlaw, hero, magician, jester, everyman and lover (see Kooskora and Isok, 2014; Moxes 2013). However, they have not linked those archetypes to transformational leadership. The next section illustrates how the identified CEO leadership archetypes (i.e. personification of leadership qualities in situational contexts) as a representation of transformational leadership were mapped onto the CVF framework.

\section{Results and Discussion}

The review of the selected articles revealed that the findings of recent research on leadership in situational contexts could be fit into each CVF quadrant. These research works used primary data sources (i.e. critical studies of 
leadership, surveys of organisational leaders and members and direct observations by leadership scholars) and secondary data sources (i.e. leadership portrayals by image generators such as corporate documents, analyst reports, publications and mass media). The findings are detailed in the next two subsections: studies using primary data sources (see Figure 2) and studies using secondary data sources (see Figure 3).

\subsection{Studies Using Primary Data}

Recent critical studies in Metaphors We Lead By suggest that leadership is simultaneously influenced by leaders, followers and contexts (see Alvesson and Spicer, 2011). The studies examined leadership from critical perspectives and presented leaders as saints, buddies, gardeners, commanders, cyborgs and bullies.

\section{Flexibility and Discretion}

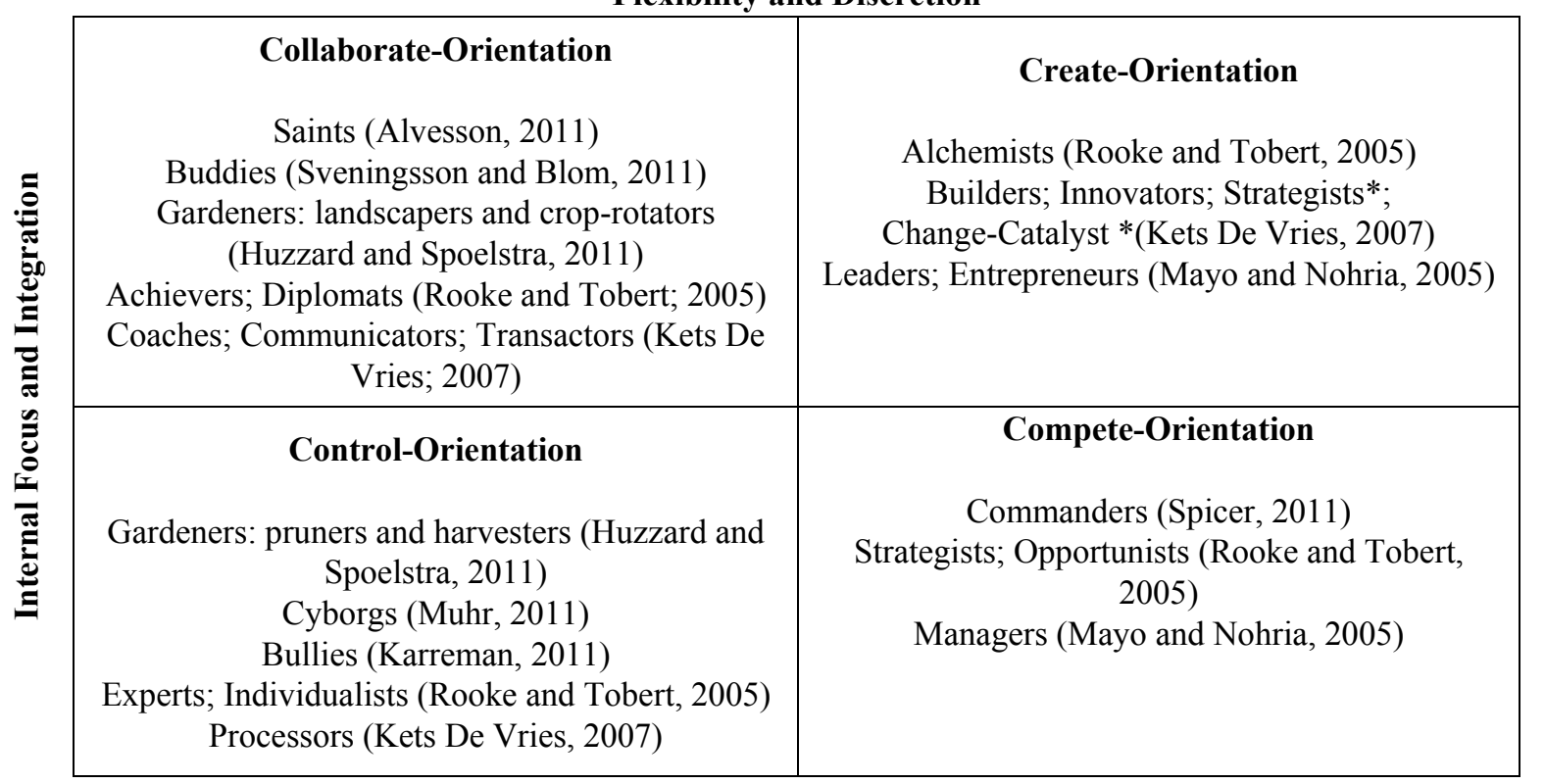

Stability and Control

*Based on the conceptual definition, these archetypes may fit into more than one quadrant.

Figure 2. Studies using primary data

Saints, who strive for moral peak performance, represent leaders who are servants to others, inner moral super(wo)men, martyrs, champions of good cause and good guys (Alvesson, 2011). Buddies, who make people feel good, are party hosts, pseudo-shrinks/therapists, equals, and ombudsmen/watchdogs (Sveningsson and Blom, 2011). As illustrated in Figure 2, both saints and buddies appear to represent leaders with the CVF collaborate-orientation. Gardeners, who facilitate growth, are sub-divided into landscapers, crop-rotators, pruners, and harvesters (Huzzard and Spoelstra, 2011). Huzzard and Spoelstra (2011) argue that landscapers and crop-rotators focus on empowerment, skills and growth, whilst pruners and harvesters focus on controls, jobs and costs. These focuses suggest that the first two sub-types of gardeners fit into the CVF collaborate quadrant, whilst the latter two sub-types fit into the CVF control quadrant. Commanders, who create clear directions, are leaders of change, ass-kickers, antagonizers, and rule breakers (Spicer, 2011). These leaders who "aim to establish a sense of social order....to drive towards victory over a well-defined enemy' (Spicer, 2001, p. 136) appear to fit into the CVF compete-orientation. Cyborgs, who ensure mechanistic superiority, are charisborgs, technocrats, and perfectionists (Muhr, 2011). Bullies, who "aim to undermine, coerce, exclude and silence" (Karreman, 2011, p. 170), are often malicious and intimidating. Both cyborgs and bullies fit into the CVF control quadrant. In essence, Metaphors We Lead By suggests that leaders play multiple metaphorical roles.

Surveys of managers and professionals in American and European companies have identified seven ways of how leaders interpret and react to situations: opportunists, experts, individualists, diplomats, achievers, strategists and alchemists (Rooke and Tobert, 2005). The surveys revealed that that strategists and alchemists were associated with high corporate performance whilst opportunists, diplomats and experts were associated with below-average performance. As illustrated in Figure 2.3, they appear to represent leaders with different CVF orientations. 
Alchemists, who generate social transformations through integrating material, spiritual and societal transformation, appear to fit into the CVF create-orientation. Strategists, who generate organisational and personal transformations through exercising power of mutual inquiry, vigilance, and vulnerability for both short-term and long-term, and opportunists, who win any way possible through exploiting situations and people, seem to be leaders with the CVF compete-orientation. Experts, who rule by logic and expertise, and individualists, who resolve gaps between strategy and performance through unique structures, represent leaders with the CVF control-orientation. Finally, diplomats, who avoid overt conflicts through bringing people together, and achievers, who meet strategic goals through teams, appear to be aligned with the CVF collaborate-orientation. Unlike, Alvessson and colleagues' (2011), Rooke and Tobert's (2005) findings suggest that leaders play both functional and metaphorical roles depending on situational contexts.

Meanwhile, surveys among organizational members categorised great American business leaders of the last century into three archetypes: entrepreneurs, (charismatic) leaders, and managers (Mayo and Nohria, 2005). As shown in Figure 2.3, entrepreneurs, who revolutionized processes, businesses, or even the whole industries, and (charismatic) leaders, who reinvigorated businesses or industries, appear to represent business leaders with the CVF create-orientation. Meanwhile, managers, who were skilled at reading and optimizing the context of their times, seem to be compete-oriented business leaders. The researchers exemplified business leaders of the twentieth century starting from 1910s to 1990s. For the 1990s, the study exemplified Jeffery P. Bezos of Amazon.com, Jerry Yang of Yahoo! and Thomas M. Siebel of Siebel Systems as entrepreneurs, Roger A. Enrico of PepsiCo, Harvey Golub of American Express Company, and Richard S. Fuld Jr. of Lehman Brothers as (charismatic) leaders, and John T. Chambers of Cisco Systems, Rochelle Lazarus of Ogilvy and Mather, and Lee R. Raymond of Exxon Mobil Corporation as managers. These findings suggest that the CEOs in the twentieth century merely played functional roles subject to situational contexts.

Instead of gathering results from surveys, (Kets De Vries, 2007; see also Kets De Vries, et al., 2010) observational studies of real leaders suggest that the effectiveness of leadership types depends on executive situational contexts. The types identified stem from the researcher's argument that individuals' effectiveness within organisations is influenced by a number of recurring patterns of behaviour called archetypes. Highly effective top executives play the role of builders, innovators, transactors, processors, coaches, communicators, strategists and change catalysts. Builders, who embrace leadership as an entrepreneurial activity, and innovators, who treat leadership as a creative idea generation task, appear to fit into the CVF create quadrant. Builders are talented and determined in making their dream come true, and are long-term oriented and work well setting up an unconventional project or other ventures inside or outside the organisation. Innovators are greatly capable of solving extremely difficult problems, long-term-oriented and always on the lookout for future possibilities.

Transactors, who see leadership as a deal-making opportunity, coaches, who embrace leadership as a people development exercise, and communicators, who treat leadership as stage management, appear to represent the CVF collaborate-orientated leaders. Transactors are good at identifying, tackling and negotiating new opportunities, acquisitions or deals, and are short-term oriented. Coaches create high performance teams and cultures, and institute cultural change. Communicators are influential among various organisational stakeholders and good at overcoming crisis situations. Meanwhile, processors, who emphasise leadership as an exercise of efficiency, appear to represent leaders with the CVF control-orientation. They establish the necessary structures and systems to support organisational objectives.

Strategists, who believe leadership is a game of chess, appear to fall in both create- and compete-orientations. They provide vision, strategic direction and outside-the-box thinking to create new form of organisations and generate future growth. They are long-term-oriented, and work best in turbulent times when changes in the environment require new directions. Change catalysts, who emphasise leadership as a turn-around activity, appear to fit into both CVF collaborate-, and create-orientations. They reengineer and create new organisational blue-prints (transformations) and work best to integrate organisational culture after a merger or acquisitions, or when spearheading a re-engineering or turn-around project. Similar to Rooke and Tobert's (2005), Kets De Vries (2007) findings suggest that leaders play both metaphorical and functional roles in situational contexts.

In general, the findings of studies using primary data sources present various labels of functional and metaphorical leadership archetypes, however, none is common across literature. 


\subsection{Studies Using Secondary Data}

While some researchers gathered leadership perceptions and impressions from primary sources through surveys and observations, other researchers conducted the same task through analysing corporate documents, market analyst reports, publications and mass media.

Flexibility and Discretion

\begin{tabular}{|c|c|}
\hline Collaborate-Orientation & Create-Orientation \\
Pedagogue; Saint (Amernic, et al., 2007) & Architect (Amernic, et al. 2007) \\
Guru; Facilitator (Oberlechener and & Messiah; Inspirator; Enlightener (Oberlechener \\
Mayer-Schonberfer, 2002) & and Mayer-Schonberfer, 2002) \\
Parent; Father; Preacher; Builder (Chen and & Mr Peanut; Maverick; Entrepreneur; Visionary \\
(Chen and Meindl, 1991)
\end{tabular}

Stability and Control

Figure 3. Studies using secondary data

An analysis of Jack Welch's letters to shareholders found that the content depicted Welch through five key metaphors: pedagogue, physician, architect, commander, and saint (Amernic, et al., 2007). The researchers framed these metaphors under the transformational leadership approach (the hybrid leadership). Similar to the studies reviewed earlier, each key metaphor could be fit into (Cameron et al., 2006) CVF for leadership (see Figure 2.3). However, this analysis also highlighted that the same CEO can evolve, moving into different quadrants of the CVF as the organisation develops. This evolution is still essentially captured in terms of metaphors suggesting different leadership archetypes. As the pedagogue, Welch sounded like a teacher who aimed to convince others about his beliefs and vision, present a management theory, clearly define management terms, and consistently tell the GE story. This initiative could be associated with efforts in engaging others' commitment to GE as suggested by the CVF collaborate quadrant. As the physician, Welch diagnosed the GE health and prescribed remedies to GE ills. The diagnosis and prescriptions were meant to identify and solve GE problems. This often required a leader to analyse the organisational strengths and weaknesses, which could be easily associated with monitoring GE agility, thus fitting into the CVF control quadrant.

As the architect, Welch defined GE organisational structure as social architecture that engaged every organisational member. The social architecture was often manifested in new organisational structures, which is the focus of the CVF create quadrant. Welch conveyed himself as the commander through using military metaphors and images, and action-oriented verbs (e.g. upgrade, expunge, dispose, shed etc.). These metaphors, images and verbs could be associated with aggressiveness which is associated with the CVF compete quadrant. As the saint, Welch was portrayed as having compassion, empowering employees and committing to social responsibility which suggests that Welch was employing the CVF collaborate-oriented leadership. Since the metaphor has been associated with the transformational leadership, these results suggest that a CEO who practises transformational leadership (the hybrid leadership) could portray his/her leadership in a number of metaphoric representations depending on the situational context.

Each metaphoric role was also contextualised into three waves of GE transformation, namely, hard, soft, and soft-cum-hard (Abetti, 2006) and framing theory (Entman, 1993). "Abetti regards a 'hard wave' as one in which 'the lives of the employees are physically disrupted by mass dismissals, divestments, acquisitions and major organizational changes'; whereas in a 'soft wave', 'the minds and habits of the employees are disturbed because they must absorb new ways of operating and new working practices"' (Amernic et al., 2007, p. 1857). The hard wave (1981-84) involved "the creation of a new vision and strategy to drive reorganisation, mass dismissals, divestments 
and acquisitions"; the soft wave (1985-95) had "the intent to revolutionise GE to gain the strengths of a big company with the leanness and agility of a small company"; the soft-and-hard wave dealt with "the intent to develop an integrated, boundaryless, stretched, total quality company with A-players" (cited in Amernic et al,. 2007, p. 1860). The hard wave appears to represent a context that requires coordination (the control quadrant) and goal attainment (the compete quadrant). The soft wave seems to suggest a context that calls for adaptation (the create quadrant). The soft-and-hard wave could be associated with a context in which organisational members have shared values and beliefs (the collaborate quadrant). Based on the three waves of GE transformation (Abetti, 2006), the study revealed that Welch projected his image as the architect (create-oriented) and commander (compete-oriented leader) during the hard wave, as the physician (control-oriented) during the soft wave, and as the saint (collaborate-oriented) during the third wave ( Amernic et al., 2007). These findings suggest that a legendary CEO such as Welch matched his metaphorical leadership archetypes to situational contexts.

Similar to Armenic et al. (2007), another content analysis of corporate documents and analyst reports illustrated the construction of CEO charisma within the US stock market and the CEOs' persona and vision during succession events through metaphors (Fanelli and Grasselli, 2006). The construction of CEO charisma was based on the charismatic leadership theory (CLT) which was represented by Ariande, the daughter of Minos and Pasiphaë. The CLT contends that charisma affects performance, that is, "effective leadership has the potential to enhance organisational performance and promote a more rewarding workplace" (Conger and Kanungo, 1998, p. 36-37). The US stock market was represented by the Minatour, a monster, to project the image of cruelty. The study suggests that Theseus (heroic CEOs) defeated the Minatour (the cruel stock market) with the help from Ariandne (the CLT) in the fight. In other words, CEOs who employ charismatic leadership tend to have powerful influence over the impressions formed by financial analysts. The impression articulated by financial analysts would influence investors' decisions. In essence, depicted as "heroic" in mass media, CEOs tend to have indirect effects on share price movements. The findings suggest that with the CLT, CEOs were heroic, which could be associated with the CVF compete-quadrant (defeating the cruel stock market, see Figure 2.3), whilst without the CLT, CEOs were non-heroic, which could be fit into the CVF control-quadrant (monitoring flow of information and financial resources).

In contrast, another analysis of written publications by leaders revealed both metaphorical leadership archetypes (i.e. commander, mechanic, Messiah, guru) and functional leadership archetypes (i.e. facilitator, inspirator and enlightener) in metaphorical organisational contexts namely, war, play, machine and spiritual experience (Oberlechener and Mayer-Schonberfer, 2002). In wars, the goal is winning at all costs and the leader is a commander, who could be placed into the CVF compete-quadrant (see Figure 2.3). In games, goals are achieved through collaboration and participation and the leader is a facilitator, who seems to have the CVF collaborate-orientation. The machine metaphor has pre-defined goals and the leader is a mechanic, who appears to have the CVF control-orientation. In spiritual experience, the leader acts as a Messiah, a guru, an inspirator, or an enlightener, and influences others to achieve goals through conviction with high ethical and moral implications. Based on leadership goals and roles, gurus, who tend to generate hopes in others, appear fit into the CVF collaborate quadrant, whilst Messiahs, inspirators, or enlighteners, who tend to be creative, appear to fall into the CVF create quadrant.

An exploration of mass media portrayals of CEOs leadership in situational contexts examined how business students perceived the leadership of Donald Burr, the founder of People Express Airline Inc. (Chen and Meindl, 1991). The study examined the portrayals of Burr in popular press media across three time periods: initial and growth stage (1981-83), mixed performance (1984-85) and merger (1986). The initial and growth stage represented the People Express' great success. The initial stage appeared to fit into the CVF create quadrant, whilst the growth stage into the compete quadrant. The mixed performance presented great expansion, loss and gains which suggested the compete-orientation. The merger stage presented the collaborate-orientation.

Based on content analysis, the study revealed 13 roles: preacher, parent/father, builder, wizard, whiz, visionary, Mr. Peanut, entrepreneur, maverick, competitor, Spartan, fighter and Fallen Hero (see Chen and Meindl's Appendix B, 1991). These images were elicited from business undergraduates who read selected articles about Burr. Some roles are metaphorical and represented familiar characters in the respondents' minds. For example, the preacher who often gave religious instructions was evoked by phrases such as "horizontal-management philosophy", "he condemns and praises", and "the messiah". The parent/father metaphor was expressed in "watched like (a) proud father", "give birth", and "the founding father". The builder metaphor was associated with Burr's priority of developing employees' commitment as a family at the company. The wizard/whiz referred to Burr's exceptional skills. This metaphor tends represent the CVF control quadrant. Mr Peanut (the logo of Planters, a company, which was started by an immigrant entrepreneur as a small business with innovative products) referred to Burr's unusual ways of doing things as captured in the phrase "peanuts fares". The entrepreneur referred to a business owner who was responsible 
for managing every aspect of his/her business. The maverick often defied established rules or practices. While roles such as the Spartan, and the hero, are metaphorical, others such as the fighter and the competitor, are functional. However, all four roles were typically associated with aggressiveness.

Of the leadership archetypes, the study revealed that the "preacher" (the collaborate-orientation) metaphor appeared consistently across three time periods and represented the unifying metaphor. The competitor (the compete-oriented leader), the wizard/whiz (the control-oriented leader) and parent/father (the collaborate-oriented leader) appeared consistently in the first situational context (i.e. the initial stage or create-orientation, and growth stage or the create-orientation and the compete-orientation) and the second situational context (i.e. the mixed performance or the compete-orientation). The Spartan, the fighter and the hero (the compete-oriented leader) appeared repetitively in the second and the third situational contexts that called for the compete-orientation and the collaborate orientation, respectively. These repetitions suggest that CEOs may have multiple predominant leadership archetypes depending on the situational context that the organisation faces.

In general, similar to leadership archetypes derived from primary data, the findings of studies based on secondary data also suggest a wide range of functional and metaphorical leadership archetypes. However, one leadership archetype (i.e. commander) was repeated across two data sources.

\section{Conclusion}

In sum, most recent research findings suggest that CEO leadership could be placed into the four quadrants of the CVF for leadership (see Figure 1). Each quadrant is represented by multiple leadership archetypes, which are personifications of abstract leadership qualities. The archetypes were inferred from accounts of CEOs' expressions and actions in situational contexts. Some of these archetypes such as achievers, communicators, processors, and strategists sound functional. Others such as diplomat, coach, gardeners, and saints are purely metaphorical.

Of the identified leadership archetypes in the academic literature, the analysis suggests that three leadership archetypes, namely, collaborate-oriented saints, create-oriented entrepreneurs, and compete-oriented commanders were cited across studies using primary and secondary data sources. However, some leadership archetypes did not fall into the same CVF quadrants. For example, builders could either demonstrate entrepreneur-like behaviors or focus on employee commitment. This suggests that builders could be either create-oriented or collaborate-oriented leaders. Similarly, gardeners may facilitate growth or control day-to-day business, whilst strategists may focus on generating personal transformations or organizational transformations. The varying situational contexts suggest that gardeners could be both create- and control-oriented, whilst strategists could be both collaborate- and create-oriented.

Nonetheless, the review confirms that research on CEO leadership tend to focus on matching leadership qualities to the contemporary business challenges faced by the companies the CEOs run. Since leadership studies implicitly aim to identify effective leadership and CEOs have been identified as part of corporate brand managements, projecting CEO leadership archetypes (i.e. the personification of leadership qualities, namely, traits and behaviours in situational contexts), instead of random information about CEOs or merely traits and/or behaviors of CEOs, to stakeholder may offer better support to enhance organizational images. However, no known study has proposed or investigated whether these leadership archetypes can influence stakeholders' perception in evaluating corporate brand managements. Thus, future research should investigate the impact of CEO leadership archetypes on corporate brand management assessments especially for profit-oriented organizations. The results of such investigations would give some insights on which leadership archetypes would be beneficial to organisations in the effort to have favourable impressions among multiple stakeholders.

\section{Acknowledgment}

The authors would like to thank University Teknologi PETRONAS, Malaysia for supporting and providing the research facilities.

\section{References}

Abetti, P.A. (2006). Case study: Jack Welch's creative revolutionary transformation of General Electric and the Thermidorean reaction (1981-2004). Creativity and Innovation Management, 15, 74-84. http://dx.doi.org/10.1111/j.1467-8691.2006.00370.x

Agle, B. R., Mitchell, R. K., \& Sonnenfeld, J. A. (1999). Who matters to CEOs? An investigation of stakeholder attributes and salience, corporate performance, and CEO values. Academy of Management Journal, 42(5), 507-25. http://dx.doi.org/10.2307/256973 
Agle, B.R., Nagarajan, N. J., Sonnenfeld, J. A., \& Srinivasan, D. (2006). Does CEO charisma matter? An empirical analysis of the relationships among organizationl performance, environmental uncertainty, and top management team perceptions of CEO charisma. Academy of Management Journal, 49(1), 161-74. http://dx.doi.org/10.5465/AMJ.2006.20785800

Alvesson, M. (2011). Leaders as saints: Leadership through moral peak performance. In M. Alvesson, and A. Spicer (Eds.), Metaphor We Lead By (pp. 51-75). Routledge: Oxon.

Alvesson, M., \& Spicer, A. (2011). Metaphors We Lead By, M. Alvesson, and A. Spicer (Eds.). Routledge: Oxon.

Amernic, J., Craig, R., \& Tourish, D. (2007). The transformational leader as pedagogue, physician, architect, commander, and saint: five root metaphors in Jack Welch's letters to stockholders of General Electric. Human Relations, 60(12), 1839-1872. http://dx.doi.org/10.1177/0018726707084916

Boal, K.B., \& Hooijberg, R. (2001). Strategic leadership research: moving on. Leadership Quarterly, 11(4), 515-549.

Burns, J. M. (1978). Leadership. New York: Harper and Row.

Cameron, K.S., Quinn, R. E., Degraff, J., \& Thakor, A. V. (2006). Competing Values Leadership, C.L. Cooper. (Ed.). Cheltenham: Edward Elgar.

Chen, C. C., \& Meindl, J. R. (1991). The construction of leadership images in the popular press: The case of Donald Burr and People Express. Administrative Science Quarterly, 36(4), 521-551.

Clardy, A. (2010). Organizational reputation: Issues in conceptualization and measurement. Corporate Reputation Review, 15(4), 285-303. http://dx.doi.org/10.1057/crr.2012.17

Collins, J. (2001). Good to Great. New York: HarperCollins Publishers Inc.

Conger, J.A., \& Kanungo, R, N. (1998). Charismatic Leadership in Organizations. Sage Publications: Thousand Oaks.

Daft, R. L. (2005). The Leadership Experience. Mason: Thompson South-Western.

Fanelli, A., \& Grasselli, N. I. (2006). Defeating the minotaur: The construction of CEO charisma on the US stock market. Organization Studies, 27(6), 811-832. http://dx.doi.org/10.1177/0170840606061070

Fanelli, Angelo. (2003). Securities Analyst Responses to CEO Charismatic Images: A Symbolic Perspective. University of Florida.

Fiedler, F. E. (1967). A Theory of Leadership Effectiveness. New York: McGraw-Hill.

Finkelstein, S., Hambrick, D. C., \& Cannella, A. A. Jr. (2009). Strategic Leadership. Oxford: Oxford University Press.

Flynn, J., \& Staw, B.M. (2004). Lend me your wallets: the effect of charismatic leadership on external support for an organization. Strategic Management Journal, 25, 309-30. http://dx.doi.org/10.1002/smj.377

Fombrun, C. J. (1996). Reputation: Realizing Value from Corporate Brand Management. Boston: Harvard Business School Press.

Fombrun, C., \& Riel, C. v. (1997). The reputational landscape. Corporate Reputation Review, 1(1), 5-13. http://dx.doi.org/10.1057/palgrave.crr.1540008

Freiden, J. B. (1984). Adverstising spokesperson effects: an examination of endorser type and gender on two audiences. Journal of Advertising Research, 24(5), 33-41.

Guthey, E., Clark, T., \& Jackson, B. (2009). Demystifying Business Celebrities. 2009: Routledge.

Harris, Lloyd C., \& Ogbonna, Emmanuel. (2001). Leadership style and market orientation: An empirical study. European Journal of Marketing, 35(5/6), 744-64. http://dx.doi.org/10.1108/03090560110388196

Hatch, M.J., \& Schultz, M. (1997). Relations between organizational culture, identity and image. (contemporary business organizations). European Journal of Marketing, 31(5-6), 356-365. http://dx.doi.org/10.1108/eb060636

Hersey, P., \& Blanchard, K H. (1982). Management of Organizational Behaviour. Utilising Human Resources $\left(4^{\text {th }}\right.$ ed.). New Jersey: Prentice Hall.

Hitt, Hoskisson, \& Ireland. (2007). Management of Strategy: Concepts and Cases. Mason: Thomson South-Western. House, R. J. (1971). A path-goal theory of leadership effectiveness. Administrative Science Quarterly, 16, 321-353. 
Hunt, J.G.J. (2004). What is leadership? In J. Antonakis, A. T. Cianciolo and R. J. Sternberg (Eds.), The Nature of Leadership. Sage Publications Ltd.: London.

Huzzard, T., \& Spoelstra, S. (2011). Leaders as gardeners: Leadership through facilitating growth. In M. Alvesson and A. Spicer (Eds.), Metaphor We Lead By (pp. 76-95). Routledge: Oxon.

Ireland, R.D., \& Hitt, M. A. (2005). Achieving and maintaining strategic competitiveness in the 21st century: the role of strategic leadership. Academy of Management Executive, 19(4), 63-77.

Jung, C. G. (1980). The Archetypes and the Collective Unconscious (The Collected Words of C.G. Jung, Vol. 9, Part 1). New Jersey: Princeton University Press.

Karreman, D. (2011). Leaders as bullies: Leadership through intimidation. In M. Alvesson, and A. Spicer (Eds.), Metaphor We Lead By (pp. 162-179). Routledge: Oxon.

Keller, K.L. (2008). Strategic Brand Management: Building, Measuring and Managing Brand Equity. New Jersey: Pearson Education.

Kets De Vries, M.F.R. (2007). Decoding the team conundrum: The eight roles executives play. Organizational Dynamics, 36(1), 28-44. http://dx.doi.org/10.1016/j.orgdyn.2006.12.002

Kets De Vries, M.F.R., Vrignaud, P., Agrawal, A., \& Florent-Treacy, E. (2010). Development and application of the leadership archetype questionnaire. International Journal of Human Resource Management, 21(15), 2848-2863. http://dx.doi.org/10.1080/09585192.2010.528668

Kitchen, P.J., \& Laurence, A. (2003). Corporate reputation: an eight-country analysis. Corporate Reputation Review, 6(2), 103-117. http://dx.doi.org/10.1057/palgrave.crr.1540193

Knox, S., \& Bickerton, D. (2003). The six conventions of corporate branding. European Journal of Marketing, 37(7/8), 996-1016. http://dx.doi.org/10.1108/03090560310477636

Kooskora, M., \& Isok, P. (2014). Ethical leadership and different leadership archetypes. International Leadership Journal, 6(3), 30-52. Retrieved from http://www.tesc.edu/documents/ILJ_Fall_2014.pdf

LeBlanc, Gaston, \& Nguyen, Nha. (1996). Cues used by customers evalutating corporate image in service firms. International Journal of Service Industry Management, $7(2), \quad 44-56$. http://dx.doi.org/10.1108/09564239610113460

Leontiades, M. (1982). Choosing the right manager to fit the strategy. Journal of Business Strategy, 3(2), 58-69. http://dx.doi.org/10.1108/eb038967

Mayo, A., \& Nohria, N. (2004). In Their Time: The Greatest Business Leaders of the Twentieth Century. Boston: Harvard Business Review.

Moxnes, P. (2013). The Hero's dream and other primordial patterns of imagery. Journal of Organizational Change Management, 26(4), 638-653. http://dx.doi.org/10.1108/JOCM-02-2013-0023

Muhr, S.L. (2011). Leaders as cyborgs: Leadership through mechanistic superiority. In M. Alvesson, and A. Spicer (Eds.), Metaphor We Lead By (pp. 138-161). Routledge: Oxon.

Newsom, D., Scott, A., \& Turk V.J. (1989). THIS IS PR - The realities of public relations. California: Wadsworth Publishing Company.

Northouse, P. G. (2010). Leadership: Theory and Practice ( $5^{\text {th }}$ ed.). Thousand Oaks: Sage Publications Inc.

Oberlechner, T., \& Mayer-Schoenberger, V. (2002). Through their own words: Towards a new understanding of leadership through metaphors, Faculty Research Working Paper Series RWP02-043 (159-175 2002). John F. Kennedy School of Government, Harvard University.

Page, G., \& Fearn, H. (2005). Corporate reputation: What do consumers really care about? Journal of Advertising Research, 45(3), 305-313.

Power, J., Whelan, S., \& Davies, G. (2008). The attractiveness and connectedness of ruthless brands: the role of trust. European Journal of Marketing, 42(5/6), 586-602. http://dx.doi.org/10.1108/03090560810862525

Reidenbach, R. E., \& Pitts, R. E. (1986). Not all CEOs are created equal as advertising spokespersons: Evaluating the effective CEO spokesperson. Journal of Advertising, 15(1), 30-46. http://dx.doi.org/10.1080/00913367.1986.10672986 
Reil, C. B. M. v., \& Fombrun, C. (2007). Essentials of Corporate Communication: Implementing Practices for Effective Reputation Management. Routledge: Oxon.

Rooke, D., \& Torbert, W R. (2005, April). Seven transformations of leadership. Harvard Business Review, 67-76. Retrived from https://hbr.org/2005/04/seven-transformations-of-leadership

Rubin, V., Mager, C., \& Friedman, H. H. (1982). Company president versus spokespersons in television commercials. Journal of Advertising Research, 22(4), 31-3

Sashkin, M. (2004). Transformational leadership: A review and synthesis. In J. Antonakis, A. T. Cianciolo and R. J. Sternberg (Eds.), The Nature of Leadership (pp. 171-196). Sage Publications: Thousand Oaks.

Shrivastava P., \& Nachman, S. A. (1989). Strategic leadership patterns. Strategic Management Journal, 10, 51-66. http://dx.doi.org/10.1002/smj.4250100706

Spicer, A. (2011). Leaders as commanders: Leadership through clear direction. In M. Alvesson, and A. Spicer (Eds.), Metaphor We Lead By (pp. 118-137). Routledge: Oxon.

Sveningsson, S., \& Blom, M. (2011). Leaders as buddies: Leadership through making people feel good. In M. Alvesson, and A. Spicer (Eds.), Metaphor We Lead By (pp. 96-117). Routledge: Oxon.

Tosi, H. L., Misangyi, V.F., Fanelli, A., Waldman, D. A., \& Yammarino, F. J. (2004). CEO charisma, compensation, and firm performance. The Leadership Quarterly, 15(3), 405-420. http://dx.doi.org/10.1016/j.leaqua.2004.02.010

Vroom, V. H., \& Jago, A. G. (1988). The New Leadership: Managing Participation in Organizations. New Jersey: Prentice-Hall.

Wade, J.B., Porac, J. F., Pollock, T. G., \& Graffin, S. D. (2008). Star CEOs: Benefit or burden. Organizational Dynamics, 37(2), 203-210. http://dx.doi.org/10.1016/j.orgdyn.2008.02.007

Waldman, D. A., Javidan, M., \& Varella, P. (2004). Charismatic leadership at the strategic level: A new application of upper echelons theory. The Leadership Quarterly, 15(3), 355-80. http://dx.doi.org/10.1016/j.leaqua.2004.02.013

Waldman, D. A., Ramirez, G, House, R. J., \& Puranam, P. (2001). Does leadership matter? CEO leadership attributes and profitability under the conditions of perceived environmental uncertainty. Academy of Management Journal, 14(1), 134-44. http://dx.doi.org/10.2307/3069341

Weber, Shandwick. (2012). The Company Behind the Brand: In Reputation We Trust--CEO Spotlight. Retrieved from http://ebookbrowse.com/ceo-spotlight-r5-uk-pdf-d380420647

Wissema, J. G., Van Der Poh, H.W., \& Messer, H. M. (1980). Strategic management archetypes. Strategic Management Journal, 1, 37-47. 